\title{
TECCIENCIA
}

\section{Using Scenedesmus sp. for the Phycoremediation of Tannery Wastewater}

\author{
Uso de Scenedesmus sp. para la Ficorremediación de Aguas Residuales de Curtiembres
}

\author{
Miguel Ballén-Segura ${ }^{1 *}$, Luisa Hernández Rodríguez ${ }^{1}$, David Parra Ospina ${ }^{1}$, Asly Vega Bolaños ${ }^{1}$, \\ Karen Pérez ${ }^{1}$ \\ ${ }^{\text {I}}$ Escuela de Ciencias Exactas e Ingeniería, Universidad Sergio Arboleda, Bogotá, Colombia
}

\begin{abstract}
Wastewater from the leather tannery industry contains high concentrations of heavy metals, especially chromium, as well as high values of inorganic nutrients and organic matter which, if not treated prior to discharge, may alter the quality of surface water bodies. As an alternative treatment to these industrial effluents, we propose the use of microalgae, due to their ability to remove contaminants. This study evaluates the growth of the microalga Scenedesmus sp. in three different dilutions of wastewater $(20 \%, 50 \%$, and $100 \%)$ at a tannery in Bogotá, Colombia, for a period of 15 days. We assess the removal of hexavalent chromium, nutrients (nitrites, nitrates, phosphates and sulfates), and Biochemical Oxygen Dilution (BOD). Results indicate a growth of Scenedesmus proportional to the dilution of the effluent, with greater biomass in undiluted wastewater. This biomass achieved the removal of $\mathrm{Cr}+6(>98 \%)$, nitrates $(>90 \%)$ and phosphates $(>99 \%)$, and BOD $(>88 \%)$ which can be attributed to a shared microalgae-bacteria effect. Thus, we conclude that the microalgae Scenedesmus sp. Used the waste effluent as a growth substrate, improving its effect during a phycoremediation process.
\end{abstract}

Keywords: Phycoremediation, Scenedesmus, Tanneries, Chromium.

\begin{abstract}
Resumen
Las aguas residuales de la industria del curtido de pieles (curtiembres) presentan elevadas concentraciones de metales pesados, especialmente de cromo, así como altos valores de nutrientes inorgánicos y materia orgánica, que de no ser tratados previa a su descarga puede alterar la calidad de los cuerpos de agua superficiales. Como un tratamiento alternativo a estos efluentes industriales, se propone el uso de microalgas, debido a su capacidad de remoción de contaminantes. En el presente trabajo se evaluó el crecimiento de la microalga Scenedesmus sp. en tres diluciones diferentes de una agua residual $(20 \%, 50 \%$ y $100 \%)$ de una Curtiembres del Barrio San Benito de la ciudad de Bogotá, por un periodo de 15 días, valorando la remoción de cromo hexavalente $(\mathrm{Cr}+6)$, nutrientes (nitritos, nitratos, fosfatos y sulfatos) y reducción de la demanda bioquímica de oxigeno (DBO). Como resultado se obtuvo un crecimiento de Scenedesmus que proporcional a la dilución del efluente, con mayor obtención de biomasa en el agua residual sin diluir. Esta biomasa redujo la concentración de $\mathrm{Cr}+6$ $(>98 \%)$ así como los nitratos $(>90 \%)$ y fosfatos $(>99 \%)$ los cuales pudieron ser tomados por la microalga para su crecimiento, pero adicionalmente se observó una reducción de nitritos ( $>98 \%)$, sulfatos $(>92 \%)$ y DBO ( $>88 \%)$ que puede ser atribuible a un efecto compartido microalga-bacteria. De esta forma se puede concluir que la microalga utilizo el efluente residual como un sustrato de crecimiento, mejorando la calidad del mismo en un proceso de ficorremediación.
\end{abstract}

Palabras clave: Ficorremediación, Scenedesmus, Curtiembres, Cromo.

*Corresponding Author.

E-mail: miguel.ballen@usa.edu.co
How to cite: Ballén-Segura, M., Hernández, L., Parra, D. Vega, A., Pérez, K., Using Scenedesmus sp. For the Phycoremediation of Tannery Wastewater, TECCIENCIA, Vol. 12 No. 21, 69-75, 2016, DOI: http:/dx.doi.org/ 


\section{TECCIENCLA}

\section{Introduction}

The transformation of leather occurs at a place known as a tannery. This process consists of several steps in which raw materials and inputs that may affect the environment are used [1]. Water is generated during the industrial process which has a significant amount of degradable organic waste, such as fats and proteins, but also a significant amount of inorganic contaminants and heavy metals, especially hexavalent chromium (VI), which is highly toxic to living beings [1] [2]. Various physicochemical methods such as filtration [3] or precipitation [4] have been used to treat wastewater from tanneries, some of which seek the recovery of chromium so that it can be used again during the process. Other methods for chromium removal or recovery in industrial effluent include ion exchange [5], the use of membranes [6], and adsorbent materials such as activated carbon [7]. These types of technology or methods have proven to be efficient, but have the disadvantage of requiring high investment and operating costs and are thus unfeasible, particularly in underdeveloped or developing countries such as is the case of Colombia.

Unlike these technologies, the use of microorganisms to treat these industrial effluents seems to be a promising field, since on the one hand it achieves the reduction of polluting compounds and on the other generates biomass, which can be used in different processes biotechnology. Within this category, the use of microalgae has attracted the most attention [8], due to its ability to reduce the concentration of inorganic nutrients such as nitrogen and phosphorus [9] [10] [11] and decrease the concentration of dissolved heavy metals such as mercury [12], cadmium and copper [13], lead [14], aluminum [15], and chromium [2]. Likewise, microalgal biomass can be used in the production of biofuels such as biodiesel [16] [17], bioethanol [17] [18], and biogas [19] [20], as well as in the production of different products of industrial and commercial interest [21] [22].

The aim of the present study is to evaluate the growth of the microalgae Scenedesmus sp. at different dilutions in tannery wastewater, determining the extent of the removal of inorganic nutrients $\left(\mathrm{NO}^{3-}, \mathrm{NO}^{2-}, \mathrm{PO}^{3-}\right.$ y $\left.\mathrm{SO}^{2-}\right)$, organic load such as BOD, and heavy metals (total chromium, hexavalent chromium, lead and cadmium)

\section{Materials And Methods}

\subsection{Sample collection}

The wastewater sample was collected in a single tannery located in the San Benito neighborhood of Bogotá, Colombia. It was taken from grease trap effluent before it entered a chemical treatment plant, and therefore consisted of a pre-treated mixture of waters from the different processes in the industry. Sample collection was carried out with one-liter amber bottles, which were refrigerated during transport to the laboratory. Once there, the sample was subdivided into four: one for heavy metal analysis, a second to determine the biochemical oxygen demand (BOD), a third for physicochemical characterization, and a final sample for microalgal growth experiments. The sample for the determination of heavy metals was adjusted to a $\mathrm{pH}$ of 2 with nitric acid and stored at $4^{\circ} \mathrm{C}$ until processing. The remaining samples were processed immediately.

\subsection{Sample characterization}

The sample obtained in the tannery was physicochemically characterized in order to evaluate the initial conditions. The parameters evaluated were conductivity (WTW COND 7310), $\mathrm{pH}$ (THERMO SCIENTIFIC STAR A211), and dissolved oxygen (WTW OXI 3310 SET 1). We additionally measured concentrations of nitrites, nitrates, sulfates, phosphates, and hexavalent chromium by UV/Visible spectrophotometry (HACH DR6000 Spectrometer), Nitrites (Diazotization USEPA method), Sulfate (USEPA 375.4 method), Phosphates (ascorbic acid USEPA 4500-P-E method) and hexavalent chromium (1,5Diphenilcarbohydrazide USEPA method). Meanwhile, the concentrations of total chromium, aluminum, cadmium, and lead were analyzed by flame atomic absorption (ContrAA700) over a previously digested sample, following Standard Methods 3111B and 3111D, and BOD by incubation for 5 days $\left(\mathrm{BOD}_{5}\right)$.

\subsection{Microalgae cultivation and the start of the experiment}

Initially, Scenedesmus sp. was isolated through a series of dilutions and plate seeding from a Bogota wetland sample and kept in Bold Basal Medium (BBM) under controlled conditions of light and temperature $\left(12: 12 \mathrm{~h}\right.$ and $\left.\sim 20^{\circ} \mathrm{C}\right)$. Each liter of BBM contained $\mathrm{NaNO}_{3} 2.50 \mathrm{~g} * 100 \mathrm{~mL}^{-1}$, $\mathrm{MgSO}_{4} 0.75 \mathrm{~g} * 100 \mathrm{~mL}^{-1}, \mathrm{NaCl} 0.25 \mathrm{~g} * 100 \mathrm{~mL}^{-1}, \mathrm{~K}_{2} \mathrm{HPO}_{4}$ $0.75 \mathrm{~g} * 100 \mathrm{~mL}^{-1}, \mathrm{KH}_{2} \mathrm{PO}_{4} 1.75 \mathrm{~g} * 100 \mathrm{~mL}^{-1}, \mathrm{CaCl}_{2} * 2 \mathrm{H}_{2} \mathrm{O}$ $0.25 \mathrm{~g} * 100 \mathrm{~mL}^{-1}, \mathrm{H}_{3} \mathrm{BO}_{3} 1.14 \mathrm{~g} * 100 \mathrm{~mL}^{-1}, \mathrm{ZnSO}_{4} * 7 \mathrm{H}_{2} \mathrm{O}$ $8.82 \mathrm{~g} * \mathrm{~L}^{-1}, \mathrm{MnCl}_{2} * 4 \mathrm{H}_{2} \mathrm{O} 1.44 \mathrm{~g} * \mathrm{~L}^{-1}, \mathrm{MoO}_{3} 0.71 \mathrm{~g} * \mathrm{~L}^{-}$ $1, \mathrm{CuSO}_{4} * 5 \mathrm{H}_{2} \mathrm{O} 1.57 \mathrm{~g} * \mathrm{~L}^{-1}, \mathrm{Co}\left(\mathrm{NO}_{3}\right)_{2} * 6 \mathrm{H}_{2} \mathrm{O} 0.49 \mathrm{~g} *$ $\mathrm{L}^{-1}$

The experiment involved evaluating the growth of Scenedesmus sp. in three different concentrations of the wastewater: $100 \%, 50 \%$, and $20 \%(\mathrm{~V} / \mathrm{V})$. Each treatment was performed three times. To do so, the effluent was diluted with distilled water and placed in $600 \mathrm{~mL}$ bottles, into which we added a $500 \mathrm{~mL}$ volume of dry culture with 


\section{TECCIENCLA}

an approximate concentration of 106 cells $/ \mathrm{ml}$ (the volume was previously centrifuged at $5000 \mathrm{rpm}$ for $5 \mathrm{~min}$, the overlaying substance was disposed of and the pellet was added to the wastewater). These treatments were maintained in cycles of $16 / 8 \mathrm{~h}$ light and a temperature of $<20^{\circ} \mathrm{C}$. A control was performed, in which the wastewater without microalgae addition was kept under the same conditions. The bottles were kept lightly closed in order to avoid loss by evaporation and no volume restitution was performed. We performed daily spectrophotometric measurements of optical density (absorbance at $660 \mathrm{~nm}$ ) for a period of 15 days, in order to estimate growth [23]. In order to do this after each treatment a $15 \mathrm{ml}$ sample was taken after a previous agitation of the bottles. These bottles were set on quartz cells in order to obtain the spectrometer reading. In order to estimate the microalgal biomass from the optical density values, dilutions from a concentrated culture from the Scenedesmus microalgae were performed, so different concentrations of the microalgae were obtained.

From each dilution the optical density and dry weight were obtained. For this last step, a $100 \mathrm{ml}$ volume was filtered from each dilution over cellulose filters, previously weighted and put to dry in an oven at $60{ }^{\circ} \mathrm{C}$ for 24 hours. After this, the filters were weighted and the dry weight was determined as the before-after weight difference. Finally, the optical density values were related to each of the microalgal biomass concentration dry weight (Figure 1) and the obtained relation was used to estimate the biomass values in the different experiments.

At the end of the 15-day period, we proceeded to centrifuge each bottle ( $5000 \mathrm{rpm}$ for $5 \mathrm{~min}$ ) in order to harvest the biomass of Scenedesmus sp., which was frozen for subsequent studies. Meanwhile, the supernatant (treated wastewater) for each concentration was collected and characterized in order to compare the initial conditions to the final conditions. The percentage of removal for each parameter was determined according to the following formula:

$R=\frac{C o-C f}{C o} \times 100$

Where $\mathrm{R}$ is the percentage of removal, Co the initial concentration of the parameter, and $\mathrm{Cf}$ the final concentration.

\subsection{Statistical analysis}

Due to the lack of normality in the data, we used a nonparametric analysis, the Kruskal-Wallis test (96\% confidence level), using the SPSS statistical package, to test the significance of the possible growth differences observed between the different dilutions of wastewater used.

Table 1 Characteristics of tannery wastewater and removal percentages during treatment with Scenedesmus sp.

\begin{tabular}{|l|c|c|c|}
\hline \multirow{2}{*}{$\begin{array}{c}\text { Physicochemical } \\
\text { parameters }\end{array}$} & \multicolumn{2}{|c|}{ Stage } & \multirow{2}{*}{$\begin{array}{c}\% \\
\text { Removal }\end{array}$} \\
\cline { 2 - 3 } & Initial & Final & ---- \\
\hline $\mathrm{pH}$ & 10.14 & 6.94 & ---- \\
\hline Conductivity & 33.6 & 21.48 & $>90.10$ \\
\hline Nitratas $\left(\mathrm{NO}_{3}^{-}\right)$ & 44.6 & $<0.4$ & $>98.93$ \\
\hline Nitrites $\left(\mathrm{NO}_{2}{ }^{-}\right)$ & 187 & $<2$ & $>99.85$ \\
\hline $\begin{array}{l}\text { Phosphates } \\
\left(\mathrm{PO}_{4}^{3-}\right)\end{array}$ & 13.23 & $<0.02$ & $>92.68$ \\
\hline Sulfates $\left(\mathrm{SO}_{4}{ }^{2-}\right)$ & 27.33 & $<2$ & $>9.28$ \\
\hline Total Chromium & 5.055 & 4.687 & 7.37 \\
\hline $\begin{array}{l}\text { Hexavalent } \\
\text { Chromium }\end{array}$ & 0.613 & $<0.010$ & $>98.37$ \\
\hline Cadmium & $<0.06$ & $<0.06$ & ---- \\
\hline Lead & $<0.1$ & $<0.1$ & ---- \\
\hline BOD $5(\mathrm{Mg} / \mathrm{L})$ & 17363 & 2085 & 88 \\
\hline
\end{tabular}

* The units are $\mathrm{Mg} / \mathrm{L}$ except for conductivity, which is given in $\mu \mathrm{S} / \mathrm{cm}$.

\section{Results And Discussion}

\subsection{Effect of the dilution of tannery wastewater on growth}

The growth of Scenedesmus sp. at three dilutions of wastewater can be seen in Figure 2. Significant differences in the growth of microalgae were evident $(\mathrm{P}<0.05)$, with respect to the treatment, obtaining higher values of biomass in undiluted water $(100 \%)$, followed by $50 \%$ dilution, and finally lower growth in the $20 \%$ concentration. During the experiment, the biomass was not observed to enter a stationary phase, indicating that the waste effluent nutrients allowed the growth during the 15 days of the experiment. Additionally, bacteria already present in the water are expected to degrade organic matter and recirculate nutrients, which can prolong the exponential growth phase of the microalgae [24]. We should also point out that Scenedesmus did not present a latency phase, especially in the 50 and $100 \%$ dilutions, increasing rapidly its biomass during the first 24 hours of the experiment.

These results are compared with those reported by Ajayan, et al. [2], who found greater growth in intermediate dilutions (25 and 50\%) of tannery water in India, attributing it to high concentrations of heavy metals present in the undiluted water.

Similarly, Balaji et al. [23] found an effect of the concentration of various heavy metals in tannery effluent, 


\section{TECCIENCIA}

such as chromium, lead, and cadmium, on the growth of the microalga Spirulina, demonstrating an inhibition of biomass at larger quantities of heavy metals. Nonetheless, the effect of metals in our study was not as clear. This is because an increase in biomass of approximately $0.15 \mathrm{mg}$ throughout the treatment was observed (Figure 1). During the sixth day, a fall was observed in the three concentrations which can be attributed to a possible methodological error upon doing the $660 \mathrm{~nm}$ absorbance reading.

The presence of inorganic nutrients also exert a direct effect on the growth of microalgae. The effluent used had the presence of nitrates and phosphates (Table 1), both utilizable by the microalgae, which allowed growth during the time of experimentation, while being reduced in concentration, primarily in undiluted water $(100 \%)$. These characteristics of industrial wastewater and the effect on the growth of microorganisms are widely recognized $[8,9$, $27,28]$ and have led many to examine their potential as alternative substrates for growth, with the aim of reducing the costs of biomass production for biotechnological processes. [21] [29] [30].

\subsection{Effect of treatment on the physicochemical properties of tannery water}

To assess the changes in the properties of tannery wastewater as a result of the microalgae treatment, we used $100 \%$ concentration because it allowed for the highest growth of Scenedesmus sp. (Figure 2). The initial and final values of the different evaluated parameters can be seen in Table 1.

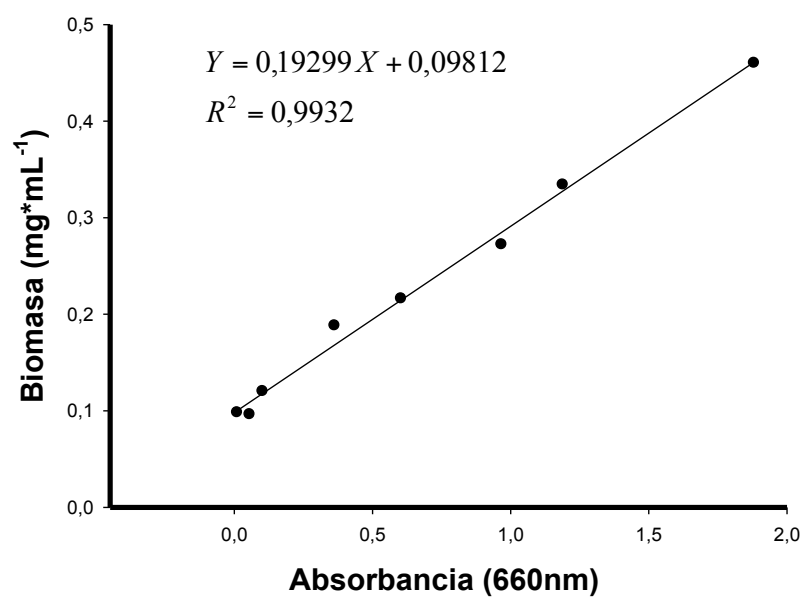

Figure 1 Biomass vs. Absorbance. Relation between Optical Density (Absorbance at 660nm) vs. dry weight of the biomass for the Scenedesmus sp. Culture.
Chromium, both total and in hexavalent form $\left(\mathrm{Cr}^{+6}\right)$, was the prominent heavy metal in the wastewaters, having initial concentrations of 5.055 and $0.613 \mathrm{mg} / \mathrm{L}$ respectively. These concentrations were reduced to $4.687 \mathrm{mg} / \mathrm{L}$ and $<0.010 \mathrm{mg} / \mathrm{L}$ after 15 days of treatment, which gives removal percentages of $8 \%$ for total chromium and $98 \%$ for $\mathrm{Cr}^{+6}$.

Other metals such as cadmium and lead were present at concentrations below the detection limits of the technique implemented. The removal percentages obtained in this study are similar to those reported by other authors [2] [31], and except for total chromium, is within the legal limits established by the 0631 resolution of 2015 for Colombia.

Although there was an almost complete removal of $\mathrm{Cr}^{+6}$ by microalgae, the reduction of total chromium was minimal, which seems to indicate that the influence of Scendesmus sp. is mainly on the hexavalent form of the metal. Han et al. [32] reported the processes of biosorption and bioreduction on $\mathrm{Cr}^{+6}$ by the microalgae Chlorella miniata.

They describe a $\mathrm{Cr}^{+6}$ adsorption by the microalgae and its subsequent reduction to $\mathrm{Cr}^{+3}$, which can be released to the medium or maintained in the biomass. It is therefore possible that Scenedesmus sp. performs the adsorption process on the $\mathrm{Cr}^{+6}$ but does not do so in the same way on the $\mathrm{Cr}^{+3}$. Similarly, the presence of other microorganisms could exert some influence, since the role bacteria can play in reductions of $\mathrm{Cr}^{+6}$ to $\mathrm{Cr}^{+3}$ has been documented [33].

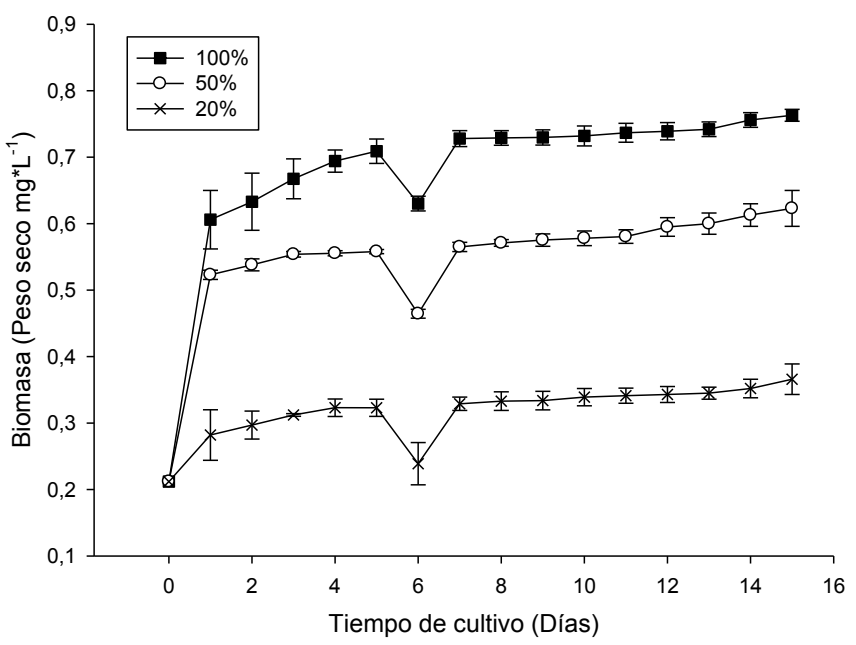

Figure 2 Biomass (Dry weight $\mathrm{mg} / \mathrm{mL}$ ) vs. Culture time (Days) for different dilutions $(20 \%, 50 \%, 100 \%)$. Effect of tannery wastewater concentration on the growth of Scenedesmus sp. 


\section{TECCIENCLA}

While the direct effect of the microalgae on the concentration of chromium seems to be evident, it may also be indirect. The process of alkalization of the medium which produces microalgal growth is well-known. This can decrease the solubility of heavy metals, leading them to react with hydroxides present and finally precipitate [34] [35].

Additionally, the study showed a decrease in the concentration of evaluated nutrients over the course of the treatment (Table 1). The nitrites and nitrates had an initial concentration of $187 \mathrm{mg} / \mathrm{L}$ and $44.6 \mathrm{mg} / \mathrm{L}$ respectively, which was reduced to $<2 \mathrm{mg} / \mathrm{L}$ and $<0.4 \mathrm{mg} / \mathrm{L}$, equivalent to approximate removal percentages of $98 \%$ and $90 \%$. The phosphates and sulfates displayed similar behavior, with removals of $99 \%$ and $92 \%$ respectively.

The ability of microalgae to remove inorganic nutrients in wastewater is a widely studied phenomenon. Elimination rates higher than 90\% have been reported [8] [9] [28] [36] [37] [38]. These nutrients are rapidly metabolized by the microalga, and nitrogen can be assimilated as ammonia or nitrates and transformed into organic nitrogen [36]. Likewise, the phosphor in the form of phosphate $\left(\mathrm{H}_{2} \mathrm{PO}_{4}{ }^{-} \mathrm{O}\right.$ $\mathrm{HPO}_{4}{ }^{2-}$ ) is used by the cell for the production of phospholipids, nucleic acids, and adenosine triphosphate (ATP), the latter essential to all cellular processes [40]. In addition, microalgae derived from photosynthetic activity that generates $\mathrm{pH}$ changes can promote the precipitation of the phosphorus and nitrogen [35].

The biochemical oxygen demand is one of the principal parameters when assessing the characteristics of wastewater. In the tannery water used in the present study, the initial $\mathrm{BOD}_{5}$ value was $17363 \mathrm{mg} / \mathrm{L}$ which was reduced during treatment with Scenedesmus sp. to $2085 \mathrm{mg} / \mathrm{L}$, showing a percentage removal of $88 \%$, higher than reported in the work of Ajayan et al. [2] for tannery waters with microalgae of the genus Scenedesmus. Although the main protagonists of the degradation of organic matter are bacteria, there is evidence of reduced BOD by microalgae [35].

On the one hand, photosynthesis generates significant amounts of oxygen which can be used by heterotrophic organisms for the oxidation of organic material [41] [42]. On the other hand, certain microalgae are known to have mixotrophic capacity, and can combine their photoautotrophic metabolism with the absorption of dissolved organic matter as an additional or complementary source of carbon for growth [43] [44].

\section{Conclusions}

In light of the above results, one can conclude that Scenedesmus sp. exhibited a clear remedial role over the tannery water, which makes it a potential alternative to complement traditional secondary wastewater treatments.

A highlight of this work is that we observed that the microalgae can grow better in undiluted wastewater, which could facilitate effluent treatment and would avoid the use of water as a dilutant.

Alternately these effluents could be used as alternative substrates for the growth of photoautotrophic microorganisms, which would generate a positive impact on the total costs of biomass production at large scales. However, further research is necessary to evaluate the biotechnological potential of this biomass, which has a high load of heavy metals and other highly polluting substances, as well as evaluating the response of other microalgal species, in order to determine whether our results can be generalized or are species-specific.

\section{Acknowledgements}

To Sergio Arboleda University for assistance and experimental support for this study. To Dr. Luisa Gonzalez and Dr. Carlos Rivera for the contributions and suggestions made to this investigation. To ECCI University for the analyses of heavy metals and Analquim for the BOD analysis. To Natalia Rivera for her help and support in the laboratory.

\section{References}

[1] Y. A. Ouaissa, M. Chabani, A. Amrane, and A. Bensmaili, "Integration of electro coagulation and adsorption for the treatment of tannery wastewater-The case of an Algerian factory, Rouiba," Procedia Engineering, vol. 33, pp. 98-101, 2012.

[2] K. V. Ajayan, M. Selvaraju, P. Unnikannan, and P. Sruthi, "Phycoremediation of tannery waste water using microalgae Scenedesmus species," International journal of phytoremediation, vol. 17, pp. 907-916, 2015.

[3] B. W. Sharp, "Chrome recycling [Tanning liquors]," Journal of the American Leather Chemists Association (USA), 1981.

[4] D. Boast, "Large scale chrome recovery from chrome wash liquors," Journal of American Leather Chemistry Association, vol. 83, pp. 1723, 1988.

[5] G. Tiravanti, D. Petruzzelli, and R. Passino, "Pretreatment of tannery wastewaters by an ion exchange process for Cr (III) removal and recovery," Water Science and Technology, vol. 36, pp. 197-207, 1997. 


\section{TECCIENCLA}

[6] R. Suthanthararajan, E. Ravindranath, K. Chits, B. Umamaheswari, T. Ramesh, and S. Rajamam, "Membrane application for recovery and reuse of water from treated tannery wastewater," Desalination, vol. 164, pp. 151-156, 2004.

[7] R. Ramos, A. Martinez, and R. Coronado, "Adsorption of chromium (VI) from aqueous solutions on activated carbon," Water Science and Technology, vol. 30, pp. 191-197, 1994.

[8] N. Abdel-Raouf, A. A. Al-Homaidan, and I. B. M. Ibraheem, "Microalgae and wastewater treatment," Saudi Journal of Biological Sciences, vol. 19, pp. 257-275, 2012.

[9] R. J. Craggs, P. J. McAuley, and V. J. Smith, "Wastewater nutrient removal by marine microalgae grown on a corrugated raceway," Water Research, vol. 31, pp. 1701-1707, 1997.

[10] Y. Li, Y.-F. Chen, P. Chen, M. Min, W. Zhou, B. Martinez, et al., "Characterization of a microalga Chlorella sp. well adapted to highly concentrated municipal wastewater for nutrient removal and biodiesel production," Bioresource technology, vol. 102, pp. 5138-5144, 2011.

[11]N. Tam and Y. Wong, "Wastewater nutrient removal by Chlorella pyrenoidosa and Scenedesmus sp," Environmental Pollution, vol. 58, pp. 19-34, 1989.

[12]N. Mallick, "Biotechnological potential of immobilized algae for wastewater N, P and metal removal: a review," Biometals, vol. 15, pp. $377-390,2002$

[13]P. A. Terry and W. Stone, "Biosorption of cadmium and copper contaminated water by Scenedesmus abundans," Chemosphere, vol. 47 , pp. 249-255, 2002.

[14] V. Gupta and A. Rastogi, "Biosorption of lead from aqueous solutions by green algae Spirogyra species: kinetics and equilibrium studies," Journal of Hazardous Materials, vol. 152, pp. 407-414, 2008.

[15]A. Sarı and M. Tuzen, "Equilibrium, thermodynamic and kinetic studies on aluminum biosorption from aqueous solution by brown algae (Padina pavonica) biomass," Journal of hazardous materials, vol. 171, pp. 973-979, 2009.

[16] Y. Chisti, "Biodiesel from microalgae," Biotechnology advances, vol. 25, pp. 294-306, 2007.

[17] Y. Chisti, "Biodiesel from microalgae beats bioethanol," Trends in biotechnology, vol. 26, pp. 126-131, 2008

[18]R. Harun, M. K. Danquah, and G. M. Forde, "Microalgal biomass as a fermentation feedstock for bioethanol production," Journal of Chemical Technology and Biotechnology, vol. 85, pp. 199-203, 2010

[19] J. H. Mussgnug, V. Klassen, A. Schlüter, and O. Kruse, "Microalgae as substrates for fermentative biogas production in a combined biorefinery concept," Journal of biotechnology, vol. 150, pp. 51-56, 2010 .

[20]R. Samson and A. Leduy, "Biogas production from anaerobic digestion of Spirulina maxima algal biomass," Biotechnology and bioengineering, vol. 24, pp. 1919-1924, 1982.

[21]L. Christenson and R. Sims, "Production and harvesting of microalgae for wastewater treatment, biofuels, and bioproducts," Biotechnology advances, vol. 29, pp. 686-702, 2011.

[22] T. C. Adarme-Vega, D. K. Lim, M. Timmins, F. Vernen, Y. Li, and P. M. Schenk, "Microalgal biofactories: a promising approach towards sustainable omega-3 fatty acid production," Microb Cell Fact, vol. 11, p. 96, 2012.

[23]A. D. Eaton, L. S. Clesceri, E. W. Rice, and A. E. Greenberg, "Standard methods for the examination of water and wastewater," 2008 .

[24]F. Azam, T. Fenchel, J. Field, J. Gray, L. Meyer-Reil, and F. Thingstad, "The ecological role of water-column microbes in the sea," Marine ecology progress series. Oldendorf, vol. 10, pp. 257-263, 1983.

[25] S. Balaji, T. Kalaivani, C. Rajasekaran, M. Shalini, R. Siva, R. K. Singh, et al., "Arthrospira (Spirulina) Species as Bioadsorbents for Lead, Chromium, and Cadmium-a Comparative Study," CLEANSoil, Air, Water, vol. 42, pp. 1790-1797, 2014.

[26]K. Arunakumara and X. Zhang, "Heavy metal bioaccumulation and toxicity with special reference to microalgae," Journal of ocean university of china, vol. 7, pp. 60-64, 2008

[27]P. Chevalier and J. de la Noüe, "Efficiency of immobilized hyperconcentrated algae for ammonium and orthophosphate removal from wastewaters," Biotechnology letters, vol. 7, pp. 395-400, 1985.

[28]P. Chevalier and J. de la Noüe, "Wastewater nutrient removal with microalgae immobilized in carrageenan," Enzyme and microbial technology, vol. 7, pp. 621-624, 1985

[29]A. F. Aravantinou, M. A. Theodorakopoulos, and I. D. Manariotis, "Selection of microalgae for wastewater treatment and potential lipids production," Bioresource technology, vol. 147, pp. 130-134, 2013.

[30]L. Brennan and P. Owende, "Biofuels from microalgae-a review of technologies for production, processing, and extractions of biofuels and co-products," Renewable and sustainable energy reviews, vol. 14, pp. 557-577, 2010.

[31]J. Pena-Castro, F. Martınez-Jerónimo, F. Esparza-Garcia, and R. Canizares-Villanueva, "Heavy metals removal by the microalga Scenedesmus incrassatulus in continuous cultures," Bioresource Technology, vol. 94, pp. 219-222, 2004

[32]X. Han, Y. S. Wong, M. H. Wong, and N. F. Y. Tam, "Biosorption and bioreduction of $\mathrm{Cr}$ (VI) by a microalgal isolate, Chlorella miniata," Journal of hazardous materials, vol. 146, pp. 65-72, 2007.

[33]E. L. Hawley, R. A. Deeb, M. C. Kavanaugh, and J. A. Jacobs, "Treatment technologies for chromium (VI)," Chromium (VI) handbook. CRC Press, Boca Raton, pp. 275-310, 2004.

[34]R. W. Peters and L. Shem, "Separation of heavy metals: removal from industrial wastewaters and contaminated soil," Argonne National Lab., IL (United States). Energy Systems Div.1993.

[35]R. Muñoz and B. Guieysse, "Algal-bacterial processes for the treatment of hazardous contaminants: a review," Water research, vol. 40, pp. 2799-2815, 2006.

[36] M. Jimenez-Perez, P. Sanchez-Castillo, O. Romera, D. FernandezMoreno, and C. Pérez-Martınez, "Growth and nutrient removal in free and immobilized planktonic green algae isolated from pig manure," Enzyme and Microbial Technology, vol. 34, pp. 392-398, 2004.

[37]P. Lau, N. Tam, and Y. Wong, "Wastewater nutrients ( $\mathrm{N}$ and P) removal by carrageenan and alginate immobilized Chlorella vulgaris," Environmental Technology, vol. 18, pp. 945-951, 1997. 


\section{TECCIENCIA}

[38] M. Martınez, S. Sánchez, J. Jimenez, F. El Yousfi, and L. Munoz, "Nitrogen and phosphorus removal from urban wastewater by the microalga Scenedesmus obliquus," Bioresource technology, vol. 73, pp. $263-272,2000$

[39] R. Inokuchi, K. i. Kuma, T. Miyata, and M. Okada, "Nitrogenassimilating enzymes in land plants and algae: phylogenic and physiological perspectives," Physiologia Plantarum, vol. 116, pp. 1$11,2002$.

[40]E. W. Becker, Microalgae: biotechnology and microbiology vol. 10: Cambridge University Press, 1994.

[41]R. Muñoz, C. Köllner, B. Guieysse, and B. Mattiasson, "Photosynthetically oxygenated salicylate biodegradation in a continuous stirred tank photobioreactor," Biotechnology and bioengineering, vol. 87, pp. 797-803, 2004.

[42]J. Grobbelaar, C. Soeder, J. Groeneweg, E. Stengel, and P. Hartig, "Rates of biogenic oxygen production in mass cultures of microalgae, absorption of atmospheric oxygen and oxygen availability for wastewater treatment," Water Research, vol. 22, pp. 1459-1464, 1988

[43]A. Bhatnagar, S. Chinnasamy, M. Singh, and K. Das, "Renewable biomass production by mixotrophic algae in the presence of various carbon sources and wastewaters," Applied Energy, vol. 88, pp. 34253431, 2011.

[44] A. P. Abreu, B. Fernandes, A. A. Vicente, J. Teixeira, and G. Dragone, "Mixotrophic cultivation of Chlorella vulgaris using industrial dairy waste as organic carbon source," Bioresource technology, vol. 118, pp. 61-66, 2012. 